PNL-2513

UC-60

\title{
Report From a Working Group Meeting on Wind Forecasts for WECS Operation
}

Larry L. Wendell

Harry L. Wegley

M. Gary Verholek

March 1978

Prepared for the U.S. Department of Energy under Contract EY-76-C-06-1830

Pacific Northwest Laboratory

Operated for the U.S. Department of Energy by 


\title{
NOTICE
}

This report was prepared as an account of work sponsored by the United States Government. Neither the United States nor the Department of Energy, nor any of their employees, nor any of their contraciors, subcontractors, or their employees, makes any warranty, express or implied, or assumes any legal liability or responsibility for the accuracy, completeness or usefulness of any information, apparatus, product or process disclosed, or represents that its use would not infringe privately owned rights.

The views, opinions and conclusions contained in this report are those of the contractor and do not necessarily represent those of the United States Government or the United States Department of Energy.

\author{
PACIFIC NORTHWEST LABORATORY \\ operated by \\ BATTELLE \\ for the \\ UNITED STATES DEPARTMENT OF ENERGY \\ Under Contract EY-76-C-06-1830
}

\begin{tabular}{|c|c|}
\hline \multicolumn{2}{|c|}{$\begin{array}{c}\text { Printed in the United States of Am } \\
\text { Available from } \\
\text { National Technical Information Ser } \\
\text { United States Department of Comm } \\
5285 \text { Port Royal Road } \\
\text { Springtield, Virginia } 22151\end{array}$} \\
\hline Price: Printed Copy & _; Microfi \\
\hline "Pages & $\begin{array}{c}\text { NTIS } \\
\text { Selling Price }\end{array}$ \\
\hline $001-025$ & $\$ 4.00$ \\
\hline $026-050$ & $\$ 4.50$ \\
\hline $051-075$ & $\$ 5.25$ \\
\hline $076-100$ & $\$ 6.00$ \\
\hline $101-125$ & $\$ 6.50$ \\
\hline $126-150$ & $\$ 7.25$ \\
\hline $151-175$ & 58.00 \\
\hline $176-200$ & $\$ 9.00$ \\
\hline $201-225$ & $\$ 9.25$ \\
\hline $226-250$ & $\$ 9.50$ \\
\hline $251-275$ & $\$ 10.75$ \\
\hline $276-300$ & $\$ 11.00$ \\
\hline
\end{tabular}


REPORT FROM A WORKING GROUP MEETING ON WIND FORECASTS FOR WECS OPERATION

Larry L. Wendell

Harry L. Wegley

M. Gary Verholek

March 1978

Prepared for the U.S. Department of Energy under Contract EY-76-C-06-1830

Pacific Northwest Laboratory Richland, Washington 99352 


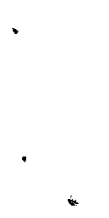




\section{SUMMARY}

A working-group discussion to identify the specific windforecasting needs of utilities and the current short-term wind forecasting capabilities was held at Pacific Northwest

Laboratory (PNL) in Richland, Washington, on December 15, 1977. Prior to the meeting, an attempt was made to ascertain the interest in and the needs for wind forecasting for wind energy conversion systems (WECS) in the dispatching and/or scheduling of wind-energy generation in a utility system. This information was gathered from utility dispatchers through telephone interviews and was presented during the working-group discussion by Gary Verholek (PNL). In these interviews, operations personnel indicated that they had given little attention to wind energy and were reluctant to use wind power as part of the base power load. Generally, they agreed that if wind forecasts were sufficiently reliable, the following types of forecasts could be used:

- weekly forecasts of day-to-day wind-power levels for use in maintenance scheduling

- daily forecasts of hourly wind-power levels to be factored into the load-scheduling strategy

- hourly forecasts of expected wind-power levels for dispatching decisions, such as buying and selling power.

At this stage of development, however, the burden rests with researchers to investigate the applicability and reliability of wind forecasting, because little information is available upon which to evaluate either area.

After discussing the applicability and reliability of wind forecasting for WECS operations, the working group recommended that: 
1) the Electric Power Research Institute (EPRI) loadscheduling model be used to evaluate the usefulness of wind forecasts;

2) the most appropriate wind-averaging interval in wind-power forecasts and the need to forecast the variability about the average be determined;

3) objective forecast techniques be verified at an operational WECS site;

4) a comprehensive pilot program at a wind-turbine generator site be established to identify utility needs and reliability of forecasts and to handle any unanticipated problems.

In order to keep abreast of wind-forecasting needs of potential WECS users and to stimulate them to anticipate their needs, PNL recommends:

- maintaining and possibly expanding, through the use of a questionnaire, contacts with operations personnel of utility companies

- establishing close contact with the utility company in Clayton, New Mexico, whose needs are based on actual experience with an operating WECS

- determining the nature and extent of the wind-forecasting needs of small WECS users.

However, if existing forecasting techniques are not appropriate to meet specific needs for WECS operations, the development of wind-forecasting techniques that will meet these needs should proceed carefully in order to determine the feasibility of such a commitment. 


\section{CONTENTS}

SUMMARY. . . . . . . . . . . . . . . . . . . . . .

INTRODUCTION • • • • • • • • • • • • • • • • • • • • • • 1

PRESENTATIONS . . . . . . . . . . . . . . . . . . 3

WIND-FORECASTING NEEDS FOR WECS OPERATIONS. • • • • • 3

WIND-FORECASTING ACCURACY . . . . . . . . . . . 5

COASTAL AND OFFSHORE WIND FORECASTING . . . . . . . . 7

NATIONAL WEATHER SERVICE WIND-FORECASTING PRODUCTS. • 8

AN ANALOG TECHNIQUE FOR PRODUCING PROBABILISTIC

WIND FORECASTS. • • • • • • • • • • • • • • • • 8

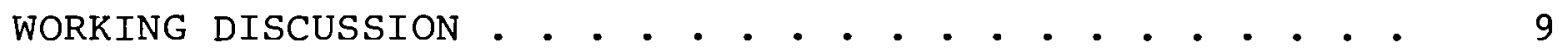

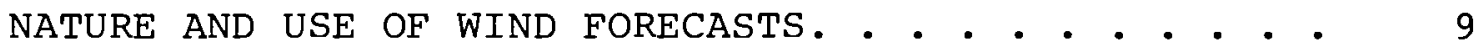

ACCURACY OF APPLICABLE FORECASTING TECHNIQUES • • • • 9

WORKING GROUP CONCLUSIONS AND RECOMMENDATION • • • • • • 11

NATURE AND USE OF FORECASTS • . . . . . . . . . . . 11

WIND CHARACTERISTICS. . . . . . . . . . . . . . 11

ACCURACY OF APPLICABLE FORECASTING TECHNIQUES . • • • 12

WIND CHARACTERISTICS PROGRAM ELEMENT COMMENTS AND

RECOMMENDATIONS . • • . . . . . . • • . . . . . . 13

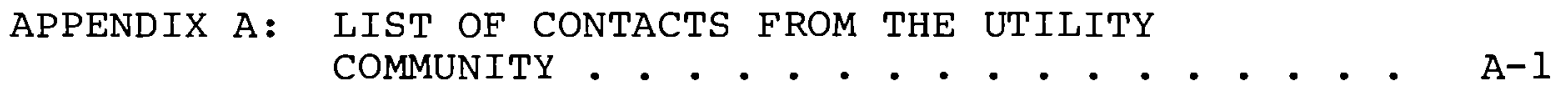

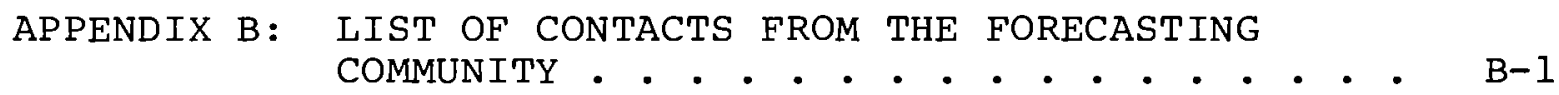




\section{$-$}




\section{INTRODUCTION}

The objective of the Federal Wind Energy Program (FWEP) is to accelerate the development of reliable and economically viable wind energy conversion systems (WECS) for commercial use. As part of the FWEP, the Wind Characteristics Program Element (WCPE) aids in accomplishing this objective in various ways. One way is the description of the day-to-day variability of wind energy in terms of predictability for WECS operations. If utilities that use WECS are to use them effectively on a dayto-day basis, operations personnel must have reliable forecasts of wind power. To this end, a working-group discussion to identify the specific wind-forecasting needs and the current short-term wind-forecasting capabilities was held at Pacific Northwest Laboratory (PNL) in Richland, washington, on December 15, 1977 .

Prior to the meeting, an attempt was made to ascertain the interest in and the need for wind forecasting for WECS in the dispatching and/or scheduling of wind-energy generation in a utility system. Relevant information from dispatchers was gathered through telephone interviews and was presented during the working-group discussion by Gary Verholek (PNL). Although utility company dispatchers were invited to the working-group discussion, only one dispatcher attended the meeting.

The meeting opened with several presentations on aspects of wind forecasting and wECS operations. The ideas presented were then discussed. At the meeting's close, recommendations were formed. This report reflects the meeting's organization, with the addition of conclusions and recommendations developed by PNL after the meeting. 


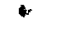




\section{PRESENTATIONS}

Five presentations were given: three by PNL and three by guests. Larry Wendell (PNL) presented an overview of the WCPE and its role in WECS operations. Most of his comments are reflected in the introduction to this report. The other presentations are discussed in this section in the order that they were presented at the meeting.

WIND-FORECASTING NEEDS FOR WECS OPERATIONS

A great deal of relevant information was gathered by Gary Verholek (PNL) through telephone interviews with utility company dispatchers. He presented this information during the group discussion. The following information is based upon both his presentation and the contribution by the one dispatcher who attended the meeting.

In the telephone interviews, utility company dispatchers were asked to assume that $10 \%$ of the installed capacity of their utility systems consisted of wind turbines. They were then asked, in view of this assumption, what kind of wind forecasts would help them factor wind power into their dispatching and scheduling strategies.

Many dispatchers indicated that most of the thinking about wind energy was done at the planning level with very little attention given to it at the operations level. Most dispatchers were concerned with immediate operational problems. Few dispatchers considered wind energy as anything more than an academic subject. However, when asked what effect wind forecasting for wind-turbine generators in their systems would have on their dispatching and scheduling, most dispatchers felt that wind-energy generation would be covered by on-line or spinning reserves, thereby eliminating the need for wind forecasting. After additional consideration, other options emerged, which 
indicated that a wind forecast, from which an accurate power estimate could be established, might be useful. These options focused on accurate wind forecasts on three time scales, ranging in importance from Cases I to III.

\section{Case I}

Weekly forecasts of day-to-day expected wind-power levels could provide some input to preventive maintenance (PM) schedules. For example, forecasts of the expected wind-power output levels, which are generated by a system, could be used in making and changing individual wind generator's PM schedules.

\section{Case II}

Daily forecasts of hourly expected wind-power levels could be factored into the scheduling strategy for the appropriate power-generation $\mathrm{mix}$. Given an accurate estimate of the wind-power output, hour-by-hour, conventional generation could be scheduled to save fuel or hydro reserves at a level equal to the expected wind-power generation.

\section{Case III}

Hourly forecasts of expected wind-power levels could enable the dispatcher to factor wind power into his dispatching strategy. The dispatcher buys and sells generated power, generally on an hourly basis, in order to maintain an adequate level of power to meet demand. He attempts to maintain an average of a 5-7\% reserve. If the utility generates more power than is needed, the power is sold to other utilities. If the utility is short of capacity, power is purchased. Since the economics of the situation have a substantial impact on the operation of the utility company as well as its dispatching strategy, the sale of excess power resulting from the wind turbine generators or equivalent generator units could be a direct savings to the utility. 
While the utilities' representatives suggested the possibilities described in Cases I, II and III, they were skeptical about existing capabilities for making sufficiently accurate forecasts. They required that wind forecasts be accurate enough to enable a power forecast to be within 2-5\% of the expected power level so that their $5-7 \%$ power reserve could be maintained. Given the wind's variable nature and the utilities' experiences with temperature forecasts for load estimates, the representatives were skeptical about the possibilities for wind forecasting. Most indicated that they were not ready to rely on wind energy in scheduling and dispatching. Although wind forecasting for WECS operations could be valuable, especially for Case III, at this stage in wind-power development, the burden of proof is on the participants in wind-energy research to investigate the applicability and reliability of wind forecasting.

\section{WIND-FORECASTING ACCURACY}

Harry Wegley, PNL, presented some problems that arise when relating wind forecasts to forecasts of WECS output power. He also discussed problems in quantifying state-of-the-art windforecasting reliability. He emphasized the need for using specific WECS operating characteristics and he stressed the need for highly accurate wind-speed forecasts, particularly in the range between the machine cut-in and rated speeds.

Harry Wegley also discussed problems caused by the variable nature of wind speed. Because variations in the wind speed produce fluctuations in the output power of a wind turbine, utilities must identify the minimum magnitude and duration of power fluctuations that would disrupt the smooth flow of power into a grid system. Once this has been done, such power fluctuations could be translated into the equivalent wind-speed fluctuations necessary to produce them. Subsequent 
studies of winds at a proposed turbine site can be conducted to determine how often such power fluctuations might occur and how accurately they can be forecast.

Prior to the working-group discussions, Mr. Wegley conducted a search for an existing set of wind-forecast verification statistics that might be used to assess the reliability of wind-speed forecasts for wind-turbine operations. He stated that he contacted the National Weather Service (NWS), Air Weather Service, Naval Weather Service, and private forecasting organizations. Ideally, the wind-forecast verification sought should include both the probability of correctly forecasting a representative wind speed over an interval of time, such as the mean hourly wind speed, and the probability of correctly forecasting the variance about the representative speed.

No ideal data sets were located in the search; however, Harry Wegley presented two sets of wind-speed-forecasting verifications, which were fair measures of the state-of-theart's ability to forecast mean hourly wind speeds in different time frames. The data sets were the NWS wind-forecasting verifications for model output statistics forecasts, which are computer-produced, and for man-produced forecasts.

Both of these data sets include 18, 30, and 42-hr forecast verifications of the 1 -min average wind for 94 air terminals in the continental United States. Verifications were performed only when winds were forecast to be at least 8 knots.

Overall, no significant difference in accuracy was indicated between man and computer-produced forecasts. The speedforecast errors increased over time up to $30 \mathrm{hr}$, then reached a plateau. When several stations were grouped by terrain into categories such as Plains, East Coast, West Coast, and Mountains, the following results were observed: 
- The largest mean speed error occurred in the mountains; the smallest in the plains.

- Only the mean speed error for the mountains was significantly different from that of the others.

- The variability in speed errors among mountain stations was so great that generalizations about wind-forecasting reliability are not valid in complex terrain.

From the NWS data the following conservative estimates of error were made concerning the state-of-the-art ability to forecast wind speeds with averaging times longer than 1 min:

\begin{tabular}{cc}
$\begin{array}{c}\text { Time Frame } \\
\text { from forecast time) }\end{array}$ & $\begin{array}{c}\text { Error Range } \\
\text { (knots) }\end{array}$ \\
\hline 18 & $\pm 2-4$ \\
30 & $\pm 3-6$ \\
42 & $\pm 3-6$
\end{tabular}

The NWS data also suggests that it may not be possible to accurately characterize speed-forecast errors by site terrain type.

At the present time, little information is available with which to evaluate wind-forecasting reliability. Also very little information exists, which relates the applicability of available forecast products to needs in wind-power use.

COASTAL AND OFFSHORE WIND FORECASTING

James Dykas, Oceanographic Services, Inc., presented some objective wind-forecasting techniques and their observed accuracies at coastal and offshore sites. He suggested that if sufficient onsite data are available, site-specific predictors can be selected from which highly accurate wind forecasts can be produced. 
NATIONAL WEATHER SERVICE WIND-FORECASTING PRODUCTS

Matthew Kulaweic, NWS, Seattle, presented the current array of NWS numerical models and the derived forecast products. He also mentioned models planned for the near future. He discussed factors such as generalized (rather than specific) forecasting, centralized forecasting, and a shrinking data base, which place limitations upon the NWS. Depending upon the need and proper approval, both model outputs and locally produced forecasts could be tailored to meet wECS operational needs.

AN ANALOG TECHNIQUE FOR PRODUCING PROBABILISTIC WIND FORECASTS

Michael Cuming, Meteorology International, Inc., discussed a sophisticated analog approach to wind forecasting for WECS. He suggested that this technique be applied to construct a forecast probability distribution of wind speed from which the probability of available wind power could be obtained. 


\section{WORKING DISCUSSION}

Following the presentations, the discussion was opened to all members of the working group to isolate the types of wind forecasts needed by utilities, to determine how these forecasts might best be used, and to determine if sufficiently reliable forecasting techniques exist to produce the needed forecasts.

NATURE AND USE OF WIND FORECASTS

The working group discussed various problems facing operational dispatchers. Although dispatchers were extremely reluctant to rely on forecasts of wind power as part of the base load, they felt that accurate forecasts could be used advantageously in 24-hr load-scheduling strategies. It was suggested that these forecasts should be probabilistic rather than deterministic if they are to be used for decision making.

Utility personnel suggested only one use of wind-power forecasts in the hour-to-hour operations. They said that accurate short-term power forecasts might be used to maintain as many generators as possible at peak efficiency levels rather than at peak power levels. In this way, savings might be realized without relying on wind energy for part of the base load. However, no methods of accomplishing this were suggested.

\section{ACCURACY OF APPLICABLE FORECASTING TECHNIOUES}

No data sets were available with which to quantitatively assess the accuracy of the forecast techniques presented. However, some of the forecasters felt that reliable deterministic or probabilistic wind forecasts can be made from available objective techniques. Generally, these techniques have to be carefully tailored to a specific location. 


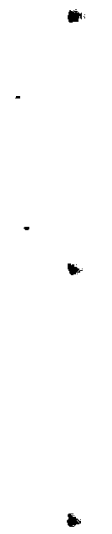


WORKING GROUP CONCLUSIONS

AND RECOMMENDATIONS

At the conclusion of the discussion session, several questions were still unanswered. Consequently, the working group was asked to formulate a list of recommendations for determining the needs of utilities in WECS operations and for determining the ability of current wind-forecasting technology to meet those needs. The remainder of this section is a compilation of those recommendations.

NATURE AND USE OF FORECASTS

A demonstration of the usefulness of wind-power forecasts is necessary, because very little is known about the need and possible uses of wind-power forecasts. One demonstration method suggested employing the Electric Power Research Institute (EPRI) load-scheduling model. By incorporating wind energy into this model and then running it with various accuracies of wind forecasts, requirements for forecasting reliability could be assessed.

It was also suggested that a comprehensive pilot program be established in cooperation with a potential WECS-operating utility. Such a program would help to identify the forecast needs of utilities, the state-of-the-art ability to meet those needs, and any unanticipated operational problems.

\section{WIND CHARACTERISTICS}

A study should be performed with data from an operational wind turbine, such as the one at Clayton, New Mexico, in order to isolate the wind characteristics that can best be used to forecast hourly power output. This study would help determine the appropriate averaging interval necessary for wind forecasts and the need for a forecast of the variability about the 
average. The analysis would also provide an excellent opportunity for wind-forcasting verification.

ACCURACY OF APPLICABLE FORECASTING TECHNIQUES

Because available wind-forcasting verification information is inadequate to evaluate the reliability of wind-power forecasts, the working group suggested that a private firm or the Techniques Development Laboratory of the National Oceanic and Atmospheric Administration (NOAA) be asked to produce objective wind forecasts that are based on the most appropriate existing forecast techniques for an operational WECS site. This effort should also include a comprehensive verification analysis. The results should represent the most definitive information on wind-forecasting reliability for WECS operations. 


\section{WIND CHARACTERISTICS PROGRAM ELEMENT \\ COMMENTS AND RECOMMENDATIONS}

The working-group meeting and the telephone interviews were the initial step in defining the need for wind forecasting in WECS operations and in determining the availability and reliability of appropriate wind-forecasting techniques. After the meeting, PNL made the following recommendations in order to keep abreast of wind-forecasting needs of potential WECS users and to stimulate them to anticipate their needs.

- Contacts with the operations personnel of utility companies should be maintained and possibly expanded, using a questionnaire.

- Close contact should be established with the utility company in Clayton, New Mexico, whose needs are based on actual experience with an operating WECS.

- A survey determining the nature and extent of the windforecasting needs of small WECS users should be made. The following recommendations will become more important as specific wind-forcasting needs of WECS users become more clearly defined.

- The type of forecast products required by utilities should be established, and the acceptable limits of uncertainty in each type of forecast should be specified.

- The forecast products, currently available from government and private sources, should be surveyed to determine if any products would be appropriate in type and reliability.

- If existing forecasting techniques are not appropriate to meet specific needs for WECS operations, development of wind-forecasting techniques that will meet these needs should proceed carefully in order to determine the feasibility of such a commitment. 
- Efforts should be made to encourage the American Meteorological society to include a wind-energy forecasting session in its next weather-forecasting symposium or workshop.

Task descriptions for specific efforts in this program area are being prepared and will be submitted for review and approval by the Wind Systems Branch. 
APPENDIX A

LIST OF CONTACTS

FROM THE UTILITY COMMUNITY

A-1 
LIST OF CONTACTS

FROM THE UTILITY COMMUNITY

Mr. E. J . Warchol

Bonneville Power Administration

P. O. Box 3621

Portland, OR 97225

Mr. Robert Johnston

Clayton Light \& Power

Main Street

Clayton, NM 88415

Dr. E. A. DeMeo

EPRI

3412 Hillview Avenue

Palo Alto, CA 94303

Mr. Tom Bouscher

Green Mt. Power Company

1 Main Street

Burlington, VT 05401

Mr. Tom McCabe

New England Gas \& Electric

675 Massachusetts Avenue

Cambridge, MA 02139

Mr. Harry Mochan

New England Power Exchange

174 Bush Hill Avenue

W. Springfield, MA 01089

Mr. Bob Goodrich

New England Utilities

F. O. Box 270

Hartford, CT 06101
Mr. Bill Flowers and

Mr. Tom Hillesland

Pacific Gas \& Electric 3400 Crow Canyon Road

San Ramon, CA 94583

Mr. Richard Wood

Niagra Mohawk Power Corp. 300 Erie Boulevard

West Syracuse, NY 13202

Mr. Neil Woodley,

Mr. Norman Sanesi, and

Mr. Bruce Snyder

Portland General Electric 121 SW Salmon Street

Portland, OR 97204

Mr. Robert Scheffler and

Mr. John Balance

Southern California Edison

P. O. Box 800

Rosemead, CA 91770

Mr. Norman Vertrees*

Grant County PUD

Ephrata, WA 98823

Mr. Roger Woodruff*

Washington Public Power

Supply System

Richland, WA 99352

\footnotetext{
${ }^{\star}$ Attended
} 
$-$

- 


\section{APPENDIX B}

LIST OF CONTACTS

FROM THE FORECASTING COMMUNITY

B-1 


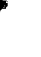


Matthew Kulaweic*

Seattle Weather Service

Forecast office

$1700 \mathrm{~W}$. Lake North

Seattle, WA 98109

Jim Dykas*

Oceanographic Services, Inc.

135 East Ortega street

Santa Barbara, CA 93101

Michael Cuming*

Meteorology International Inc.

205 Montecito Avenue

Monterey, CA 93940

John Murphy

Weather Services Corporation

131A Great Road

Bedford, MA 01730

Armand Iaccheo

Weather Corporation of America

5 American Industrial Drive

st. Louis, MO 63043

Joe Myers

ACCU-Weather, Inc.

633 West College Avenue

State college, PA 16801

Victor Cook

Midwest Weather Service Div. Commodity News Service, Inc.

P.O. Box 6053

Leawood, KS 66206

*Attended
Harvey Freese

Freese-Notis Associates, Inc.

1453 N.R. 66 Avenue

Des Moines, IA 50313

Wayne Mount

Geo-Atmospherics Corporation

P. O. Box 177

Lincoln, MA 01773

Lyle Brosche

General weather Center, Inc.

527 Fisher Building

Detroit, MI 48202

Allen weather Corporation 5207 Wisconsin Ave., N.W. Washington, D.C. 20015

Denardo and McFarland

Weather Service, Inc.

Allegheny County Airport

West Mifflin, PA 15122

International weather Corp.

P. O. Box 176

Bay Ridge Station

Brooklyn, NY 11220

R. L. Baldwin

Meteotec Inc.

P. O. Box 8489

Salt Lake City, UT 84108 
Boyd E. Quate

Boyd E. Quate \& Associates

P. O. Box 7065 - Holland Sta.

Suffolk, VA 23437

National Weather Corporation

Hangar 12 - Newark Airport

Newark, NJ 07114

John Henz

The Applied Atmospheric

Research Center

1520 E. Mulberry, Suite 100

Ft. Collins, CO 80521

Richard Knapp

York Research Corporation

1 Research Drive

Stamford, CT 06906

Major Russell Shablow

Air Force Global Weather Central

offutt Air Force Base, NE 68113

Dr. Glahn

National Weather Service

Systems Development Office

Techniques Development Laboratory

Silver Spring, MD 20910 


\section{DISTRIBUTION}

No. of

Copies

\section{OFFSITE}

A. A. Churm

DOE Chicago Patent Group

9800 South Cass Avenue

Argonne, IL 60439

G. P. Tennyson

Department of Energy

600 E Street, N. W.

Washington, DC 20545

283 DOE Technical Information Center

Thomas Vonier

AWEA Windletter

2222 Q Street, N. W.

Washington, DC 20008

Dr. Paul B. MacCready, Jr.

AeroVironment, Inc.

145 Vista Avenue

Pasadena, CA 91107

Clarissa Quinlan

Alaska State Energy Office

338 Denali Street

Anchorage, AK 99501

Paul N. Vosburgh

Alcoa Allied Products

Aluminum Company of America

Alcoa Center, PA 15069

Dr. K. C. Spengler

American Meteorological Society

45 Beacon Street

Boston, MA 02108

Ben Wolff

American Wind Energy Association

1000 Connecticut Avenue, N. W.

Suite 1111

Washington, DC 20036
No. of

Copies

\section{Richard Katzenberg}

American Wind Energy Association

Natural Power, Inc.

New Boston, NH 03070

E. J. Warchol

Bonneville Power Administration

P. 0. Box 3621

Portland, OR 97208

S. J. Hightower

Bureau of Reclamation

Denver Federal Center

Building 67, Code 254

Denver, CO 80225

M. Ginosar

California Solar Energy Commission

Energy Resources, Conservation and Development Commission

1111 Howe Avenue, Mai1 Stop 15

Sacramento, CA 95825

Robert Ball

Center for the Environment and

Man, Inc.

275 Windsor Street

Hartford, CT 06120

Dr. R. J. Hawks

Clarkson College

Potsdam, NY 13676

Dr. R. N. Meroney

Colorado State University

Fort Collins, CO 80523

E. H. Gilmore

Department of Agriculture Agriculture Research Service

Bushland, TX 79012 
No. of

Copies

L. A. Liljedahl

Department of Agriculture

Agriculture Wind Energy Program

Building 001 , Room 126 BARC-West

Beltsville, MD 20705

Douglas G. Fox

Department of Agriculture

Forest and Mountain Meteorology

Rocky Mountain Forest and Range

Experiment Station

240 West Prospect Street

Fort Collins, CO 80521

Major T. E. Kullgren

DFCEM

USAF Academy, CO 80840

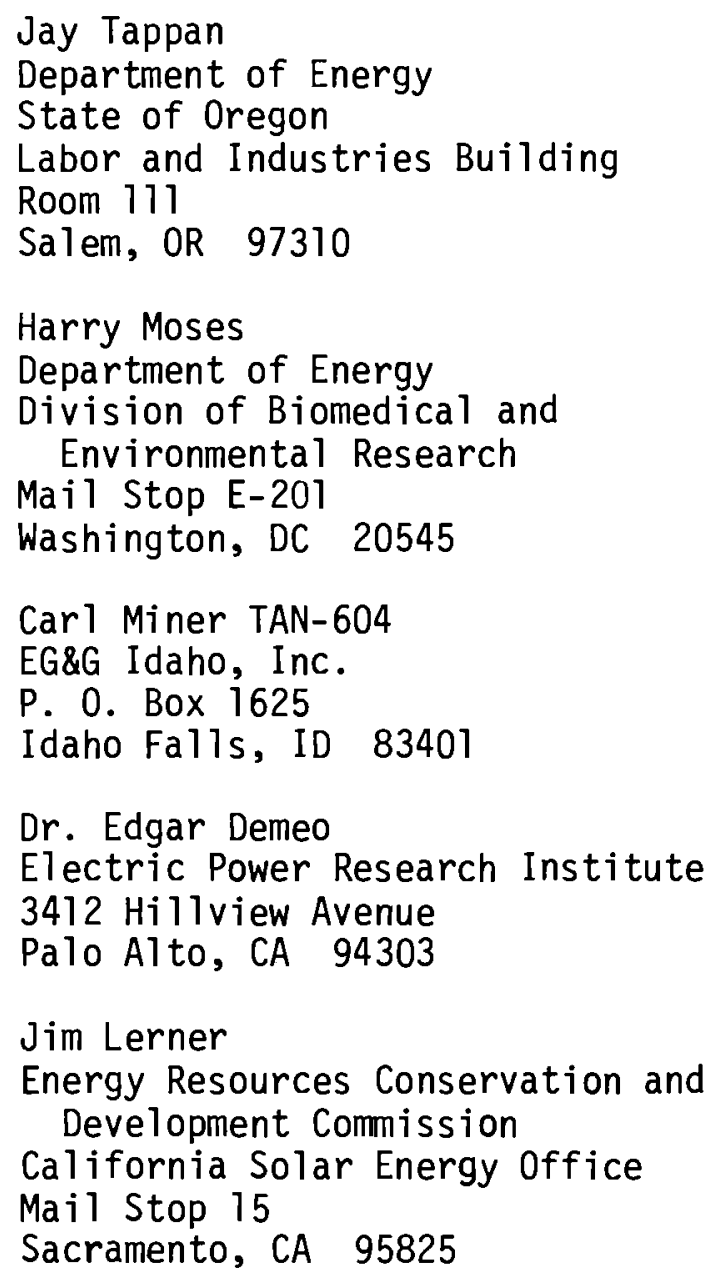

No. of

Copies

Dr. 011e Ljungstrom

FFA, The Aeronautical Research Institute

Forskningsstationen i Stockholm Drottning Kristinas Vag 47

S-114 28 Stockholm, Sweden

R. B. Lawford

Fisheries \& Environment

25 St. Clair Ave. East

Toronto, Canada M4T 1M2

Dr. W. Frost

FWG Associates, Inc.

R. R. 3, Box 331

Tullahoma, TN 37388

L. Krawitz

General Electric Company

P. 0. Box 8555

Philadelphia, PA 19101

R. C. Koch

Geomet, Inc.

15 Firstfield Road

Gaithersburg, MD 20760

C. G. Justus

Georgia Institute of Technology

Atlanta, GA 30332

J. Park

HELION, Inc.

Box 445

Brownsville, CA 95919

Dr. T. R. Kornreich

JBF Scientific Corporation

1925 North Lynn Street

Suite 308

Arlington, VA 22209

Dr. J. B. Knox

Lawrence Livermore Laboratory

University of California

P. 0. Box 808

Livermore, CA 94550 
No. of

Copies

Ms. Abbey Page

Maine Office of Energy Resources

55 Capitol

Augusta, ME 04330

S. M. Howard

Meteorology Research, Inc.

P. 0. Box 637

Altadena, CA 91001

V. F. Garrett

Montana Energy and MHD Res. and

Dev. Inst., Inc.P. 0. Box 3809

Butte, MT 59701

J. Konigsberg

Montana Energy Office

Capital Station

Helena, MT 59601

Phillip French

NASA Scientific and Technical Information Facility

P. 0. Box 8757

Baltimore/Washington International

Airport

MD 21240

R. A. Wolf

NASA/Lewis Research Center

Mail Stop 500-201

Cleveland, $\mathrm{OH} \quad 44135$

M. J. Changery

National Oceanic and Atmospheric

Administration

National Climatic Center

Federal Building

Asheville, NC 28801

R. J. Templ in

National Research Council of Canada

National Aeronautical Establishment

M-2 Montreal Road

Ottawa, Ontario K1A or 6
No. of

Copies

Ms. Peggy McDonald

N. E. Solar Energy Center

70 Memorial Drive

Cambridge, MA 02142

P. W. Blakeley

New Zealand Electricity

Rutherford House

Lambton Quay

Wellington, New Zealand

M. W. Edelstein

North American Weather Consultants 600 Norman Firestone Road

Goleta, CA 93017

R. B. Corotis

Civil Engineering - Tech.

Northwestern University

Evanston, IL 60201

E. W. Hewson

Oregon State University

Corvallis, OR 97331

R. de Violini

Pacific Missile Test Center CODE 3250-3

Point Mugu, CA 93042

S. C. Crow

Poseidon Research

11777 San Vincente B1vd.

Suite 641

Los Angeles, CA 90049

D. Tompkins

PRC Eng. Analysis Co.

$760001 d$ House Road

McLean, VA 22102

Dr. F. M. Vukovich

Research Triangle Institute

P. 0. Box 12194

Research Triangle Park, NC 27709 
No. of

Copies

Terry J. Healy

Rockwel 1 Internationa 1

Rocky Flats Plant

P. 0. Box 464

Golden, CO 80401

2 R. E. Akins/J. W. Reed

Sandia Laboratories

Division 5443

P. 0. Box 5800

Albuquerque, NM 87115

R. M. Traci

Science Applications, Inc.

P. 0. Box 2351

La Jolla, CA 92038

D. M. Hardy

Solar Energy Research Institute

1536 Cole Bivd.

Golden, CO 80401

Dr. C. M. Bhumralkar

Stanford Research

Institute, International

Menlo Park, CA 94025

C. Jump

US Army Corps of Engineers

Seattle District

P. 0. Box C 3755

Seattle, WA 98124

B. H. Bailey

State University of New York

1400 Washington Ave.

Albany, NY 12222

R. Crowder

Taylor Woodrow Construction, Limited

Taywood House

345 Ruislip Road

Southa 11

Middlesex UBI 2QX

England
No. of

Copies

Dr. T. Wentink, Jr.

University of Alaska

Fairbanks, AK 99701

Dr. P. Yuen

University of Hawaij at Manoa

Holmes Ha11 240

2540 Dole Street

Honolulu, HI 96822

C. E. Duchon

University of $0 k 1$ ahoma

200 Felgar Street

Norman, OK 73069

Dr. N. K. Wagner

Dept. of Civil Engineering

University of Texas

Austin, TX 78712

Dr. M. Garstang

University of Virginia

Charlottesville, VA 22903

Dr. R. W. Marrs

University of Wyoming

Laramie, WY 8207

David Kapus

Washington State Division of

Engineering and Architecture

106 Maple Drive

Olympia, WA 98504

Ms. Susan Hosch

Washington State Energy Office 400 E. Union Avenue, lst Floor Olympia, WA 98504

R. K. Woodruff

Washington Public Power Supply System

P0. Box 968

Richland, WA 99352 
No. of

Copies

S. R. Epur

Wichita State University

P. 0. Box 44

Wichita, KS 67208

ONSITE

2 DOE Richland Operations Office

P. 0. Box 550

Richland, WA 99352

G. L. Liffick

H. E. Ransom

33 Pacific Northwest Laboratory

Battelle Boulevard

Richland, WA 99352

R. L. Contey

J. C. Doran

R. L. Drake

C. E. Elderkin (5)

D. L. Elliot

M. M. Orgi11

P. M. Partch

W. T. Penne11

E. H. Phinney

J. V. Ramsde 11

D. S. Renne

C. L. Simpson

L. L. Wende11 (10)

Technical Information - Library (5)

Publishing Coordination (2) 
